we respect the views of schools who do not advise postexposure prophylaxis because self prescribing of potentially toxic drugs without supervision is too risky, a seven day course is unlikely to cause serious side effects and starter packs give students time to seek expert advice and follow up.

Schools should balance the educational advantages of electives with the health risks involved. At the very least they should provide updated advice on bloodborne virus infections, travel vaccinations, and general hazards such as unprotected sexual intercourse, assault, and political instability. Advice could be centrally provided.

We thank the Council of Heads of Medical Schools, particularly the secretary, Mr Michael Powell, for help.

Contributors: AJT designed the questionnaire, analysed results, and wrote the paper jointly with JEB, who also liaised with the
Council of Heads of Medical Schools. AJT is guarantor. An unabridged version of this paper is available on the CHMS website (www.chms.ac.uk)

Funding: Divisional resources.

Competing interests: None declared.

1 Gamester CF, Tilzey AJ, Banatvala JE. Medical students' risk of infection with blood borne viruses at home and abroad; questionnaire survey. $B M J$ 1999;318:158-60

2 Moss PJ, Beeching NJ. Provision of health advice for UK medical students planning to travel overseas for their elective study period: questionnaire survey. BMJ 1999;318:161-2.

3 UK Health Departments. HIV post-exposure prophylaxis: guidance from the UK chief medical officers'expert advisory group on AIDS. London: $\mathrm{DoH}, 2000$.

4 Karstaedt AS, Pantanowitz L. Occupational exposure of interns to blood in an area of high HIV seroprevalence. S Afr Med J 2001;91:57-61.

5 Franklin GS, Gray K, Nathwani D. Provision of drugs for post-exposure prophylaxis of HIV for medical students on overseas electives. J Infect 2001;43:191-4.

(Accepted 18 April 2002)

\title{
Maternal smoking and risk of hypertrophic infantile pyloric stenosis: 10 year population based cohort study
}

\author{
Henrik Toft Sørensen, Bente Nørgård, Lars Pedersen, Helle Larsen, Søren Paaske Johnsen
}

Infantile hypertrophic pyloric stenosis affects 0.5 to 3.0 per 1000 live births. ${ }^{12}$ The aetiology is unclear, but family history and sex distribution seem important and might indicate a genetic role. ${ }^{3}$ However, a recently reported fall in the incidence of infantile hypertrophic pyloric stenosis suggests that environmental factors are also important. ${ }^{4}$ During the last decade a similar reduction in the proportion of pregnant women who smoke was reported in Denmark, ${ }^{5}$ raising the possibility that maternal smoking is a risk factor for infantile hypertrophic pyloric stenosis. This hypothesis is supported by the reported ecological association between infantile hypertrophic pyloric stenosis and sudden infant death syndrome. ${ }^{1}$ Maternal smoking is also a risk factor for sudden infant death syndrome, and we therefore examined whether maternal smoking was a risk factor for infantile hypertrophic pyloric stenosis in a population based Danish cohort.

\section{Methods and results}

We conducted the study between 1 January 1991 and 31 December 2000 in the Danish county of North Jutland and included data on all women who delivered a live infant after 28 weeks' gestation. The county birth registry contains information on all births since 1 January 1991. The main data comprise maternal age, self reported smoking status at the first visit to the midwife, birth order, gestational age, length and weight of neonates at birth, civil status, and civil registry numbers for both mother and child.

We identified all cases of infantile hypertrophic pyloric stenosis from the county hospital discharge registry, which contains data on all discharges from the hospitals since 1977, the civil registry number, dates of admission and discharge, surgical procedures per- formed, and up to 20 diagnoses classified according to the international classification of diseases (ICD-8 until the end of 1993 and then ICD-10). The codes for infantile hypertrophic pyloric stenosis were 750.19 (ICD-8) and Q40.0 (ICD-10). The civil registry numbers were used to link the records in both registries.

We used SAS version 8.02 for logistic regression. We estimated the risk of infantile hypertrophic pyloric stenosis among infants born to smoking mothers and non-smoking mothers adjusted for maternal age, civil status, birth order, and sex of the child.

There were 57996 births during the study, and $16725(28.8 \%)$ mothers smoked. We identified 78 cases of infantile hypertrophic pyloric stenosis, yielding a cumulative incidence of $1.3 \%$. Thirty five cases $(0.2 \%)$ occurred among maternal smokers compared with $43(0.1 \%)$ among maternal nonsmokers, giving a relative risk of 2.0. The adjusted odds ratio was also $2.0(95 \%$ confidence interval 1.3 to 3.1 , table). The correlation between the proportion of smokers and annual incidence of infantile hypertrophic pyloric stenosis per birth year was 0.65 (Spearman's $\tau=0.65, \mathrm{P}=0.04)$. The highest incidence was $0.22 \%$ in 1991 (33\% were smokers), the lowest $0.05 \%$ in 1997 (28\% smokers).

\section{Comment}

Our data suggest that maternal smoking is a risk factor for infantile hypertrophic pyloric stenosis. We cannot determine whether the association is caused by smoking during pregnancy or postnatally-that is, through breast milk or passive smoking. We were able to adjust for some risk factors, but confounding by unknown factors associated with smoking cannot be ruled out. $\begin{array}{ll}\text { Department of } & \text { Clinical } \\ \text { Epidemiology, } \\ \text { Aarhus University } \\ \text { Hospital, 8000 } \\ \text { Aarhus C, Denmark }\end{array}$ 
Risk of hypertrophic infantile pyloric stenosis according to maternal smoking status and other variables

\begin{tabular}{|c|c|c|c|}
\hline & $\begin{array}{c}\text { No of cases/total } \\
\text { births }\end{array}$ & $\begin{array}{l}\text { Crude odds ratio } \\
\qquad(95 \% \mathrm{Cl})\end{array}$ & $\begin{array}{l}\text { Adjusted odds ratio* } \\
(95 \% \text { Cl) }\end{array}$ \\
\hline \multicolumn{4}{|l|}{ Smoking status: } \\
\hline Non-smoker & $43 / 41271$ & 1 & 1 \\
\hline Smoker & $35 / 16725$ & 2.0 (1.3 to 3.1$)$ & 2.0 (1.3 to 3.1$)$ \\
\hline \multicolumn{4}{|l|}{ Sex of child: } \\
\hline Female & $10 / 28329$ & 1 & 1 \\
\hline Male & $68 / 29667$ & 6.5 (3.3 to 12.6$)$ & 6.5 (3.3 to 12.6$)$ \\
\hline \multicolumn{4}{|l|}{ Pregnancyt: } \\
\hline First & $44 / 24971$ & 1 & 1 \\
\hline Subsequent & $34 / 33022$ & $0.6(0.4$ to 0.9$)$ & $0.7(0.4$ to 1.1$)$ \\
\hline \multicolumn{4}{|c|}{ Maternal age (years): } \\
\hline$<25$ & 20/11 381 & 1 & 1 \\
\hline $25-30$ & $38 / 23828$ & $0.9(0.5$ to 1.6$)$ & $1.1(0.6$ to 1.9$)$ \\
\hline$>30$ & $20 / 22787$ & $0.5(0.3$ to 0.9$)$ & $0.7(0.3$ to 1.3$)$ \\
\hline \multicolumn{4}{|l|}{ Civil statusł: } \\
\hline Unmarried & $6 / 2586$ & 1 & 1 \\
\hline Married & $72 / 55124$ & 0.6 (0.2 to 1.3$)$ & 0.7 (0.3 to 1.6 ) \\
\hline
\end{tabular}

${ }^{*}$ Adjusted for maternal age, civil status, birth order, and sex of the child.

†3 missing values.

$\$ 1286$ missing values. collected independently of the hypothesis. The incidence corresponds closely with that previously reported. ${ }^{5}$ Any misclassification of smoking status and infantile hypertrophic pyloric stenosis will bias the risk estimates towards unity.

Contributors: HTS had the idea for the study. He discussed the idea and study design with all coauthors. BN, HL, LP, and SPJ retrieved and validated the data, and HTS and LP did the statistical analysis. HTS wrote the first draft, and all authors contributed to the final paper. HTS is the guarantor.

Funding: Western Danish Research Forum for Health Sciences. Competing interests: None declared.

1 Persson S, Ekbom A, Granath F, Nordenskjöld A. Parallel incidences of sudden infant death syndrome and infantile hypertrophic pyloric stenosis; a common cause? Pediatrics 2001;108:379-81.

2 Applegate MS, Druschel CM. The epidemiology of infantile hypertrophic pyloric stenosis in New York State, 1983 to 1990. Arch Pediatri Adolesc Med 1995; 149:1123-9.

3 Mitchell LE, Risch N. The genetics of infantile hypertrophic pyloric stenosis: a reanalysis. Am J Dis Child 1991;147:1203-11.

4 Nielsen JP, Haahr P, Haahr J. Infantile hypertrophic pyloric stenosis. Decreasing incidence. Dan Med Bull 2000;47:223-5.

5 Wisborg K, Henriksen T, Hedegaard M, Secher NJ. Smoking habits among Danish pregnant women from 1989 to 1996 in relation to sociodemographic and lifestyle factors. Acta Obstet Gynecol Scand 1998;77: 836-40.

(Accepted 22 April 2002)

\section{A memorable patient A Pyrrhic victory}

Cathy, at 17 , had come from far away to visit her aunt. When I was called from my bed to see her she was lying semiconscious on a trolley in casualty with a barely perceptible pulse and the telltale rash of fulminating meningococcal septicaemia.

Only a few week previously I had witnessed an 8 year old boy surrender in less than 24 hours to this killer, and I'd been left with a grim expertise on the condition unusual for a recently qualified house doctor. Whether this acquired skill proved helpful to Cathy I was never to find out. My triumph in keeping her alive was a high achievement in 1946, but when my own life events took me outside the hospital world into general practice I had no way of following up her progress, if that's the right word for what happened.

But the experience of the first case and some concentrated book learning didn't suffice to give me confidence. Despite the unearthly hour I telephoned the consultant I served, a courtly gentleman who had qualified in the reign of King Edward and had been brought out of retirement in 1940 to replace younger men called into the armed forces. His familiarity with meningococcal septicaemia was probably no greater than my own, but his long experience, his courtesy, and above all his self assurance helped us both.

"What do you propose to do?" he asked.

My response was well rehearsed: "I'll put her in isolation, take a blood culture, and then start her with high dose penicillin and give her DOCA. I'll also put her on a saline drip."

"That sounds right," said the consultant. "Carry on, and I'll see her in the morning." He didn't add, as he might well have done, "if she's still alive."

In 1946 penicillin came, if it came at all, as a phial of dry powder, which when diluted with sterile water looked like mulligatawny soup. It was available only to hospitals (and not all of them) and was intensely painful when injected. DOCA (desoxycorticosterone acetate) was what we used for adrenal failure while waiting another 10 years for the corticosteroids to appear. It worked sometimes.
And it worked for Cathy. In 48 hours she was conscious, if a little confused, and the next day she was smiling. We were all deceived by our own success-survival in such crises was rare, even rarer then than it is today.

She remained in hospital for several weeks, by which time the first ominous signs of impending tragedy had appeared. The huge purpuric patches that had disfigured her lower legs, instead of being absorbed, began to coalesce. Worse still, they became infected, and within a short time most of Cathy's calf muscles had become a stinking gangrenous putrefaction. Penicillin had lost its magic - no doubt the result of bacterial resistance, a concept not yet written up in the journals-and bilateral below-knee amputation was the only recourse.

After much heart searching and hand wringing by the surgeons called in to make a decision, that's what happened. I don't think it helped Cathy much, but by this time I had moved on-and even if I hadn't, coming face to face with what my brilliant diagnosis and treatment had achieved was humbling and uncomfortable.

Was there a lesson to be learnt? Even after 50 years, I still can't be sure. If there was, a lot of today's practitioners still have to learn it.

David Kerr retired general practitioner, Hatfield

We welcome articles of up to 600 words on topics such as A memorable patient, A paper that changed my practice, My most unfortunate mistake, or any other piece conveying instruction, pathos, or humour. If possible the article should be supplied on a disk. Permission is needed from the patient or a relative if an identifiable patient is referred to. We also welcome contributions for "Endpieces," consisting of quotations of up to 80 words (but most are considerably shorter) from any source, ancient or modern, which have appealed to the reader. 